- Entomologica Fennica. 10 December 1998

\title{
Studies on the Heteroptera of the Khorasan province in N. E. Iran. I. Nepomorpha, Gerromorpha, Leptopodomorpha, Cimicomorpha (Nabidae, Anthocoridae), and Pentatomorpha (Coreoidea)
}

\section{Rauno E. Linnavuori \& Mehdi Modarres}

Linnavuori, R. E. \& Modarres, M. 1998: Studies on the Heteroptera of the Khorasan province in N. E. Iran. I. Nepomorpha, Gerromorpha, Leptopodomorpha, Cimicomorpha (Nabidae, Anthocoridae), and Pentatomorpha (Coreoidea). - Entomol. Fennica 9: 237-241.

A list of Heteroptera species of the Khorasan province in N. E. Iran is published.

Rauno E. Linnavuori, Saukkokuja 10, Somersoja, FIN-21220 Raisio, Finland Mehdi Modarres, College of Agriculture, Ferdowsi University, P.O. Box 91775-1163, Mashhad, Iran

Received 9 April 1997, accepted 10 February 1998

\section{Introduction}

The Hemipteran fauna of Central, South and South-East Iran is relatively well-known (Expeditions of the Natural History in Stuttgart in 1954 and 1956, the National Museum of Natural History in Prague in 1970, 1973 and 1977, and annual field work of entomologists in the Plant Pests and Diseases Research Institute in Tehran). In contrast, much less work has been done in the Khorasan province in N. E. Iran. The present article is based on material collected by the senior author from April to July 1994 in Khorasan. The expedition was made in cooperation with the College of Agriculture of the Ferdowsi University in Mashhad.

\section{Material and methods}

Khorasan is the largest province in Iran with a total area of $313000 \mathrm{~km}^{2}$. The main part of the province is formed by a plateau of an average altitude of about $1000-1500 \mathrm{~m}$. It is traversed by mountain ranges (altitude up to $3050 \mathrm{~m}$ ), such as Kuh-e-Hazar Masied in the North and Kuh-e-Aladagh and Kuh-e-Binalud, a continuation of the Alborz ranges, from the south of Bojnurd to Neyshabur. In the North along the border of Turkmenistan there is a depression (altitude about $300 \mathrm{~m}$ ) extending from Sarakhs to Darreh Gaz. The climate is semiarid or arid. The vegetation in lower parts varies from Artemisia steppes in the North to immense semideserts and salt marshes with halophytes such as Haloxylon, Calligonum, and Tamarix in the South. At higher altitudes occur luxuriant forests with deciduous trees and mountain meadows.

During the expedition, trips were made to all principal areas in order to get a reliable result of the faunal composition of the province. A list of the findings is published below. In nomenclature and distributional data, the Catalogue of the Heteroptera of the Palaearctic Region I-II (Aukema \& Rieger 1995, 1996) and the recent monograph of the Coreoidea by Moulet (1995) were consulted.

The material collected is preserved in the Linnavuori collection and in the College of Agriculture of the Ferdowsi University in Mashhad. All material is collected by Rauno Linnavuori, if no other collector is mentioned. 


\section{List of species}

\section{Nepomorpha \\ Corixoidea \\ Corixidae \\ Cymatiainae}

Cymatia rogenhoferi (Fieber, 1864). - Lotfabad, 1 ex, 15.VI.1994. — Collected at light trap. — Pontomediterranean with a wide range from Central Europe to Italy and Central Asia.

\section{Corixinae}

Corixa affinis Leach, 1817. - Near Sabzevar, 1 ex, 31.V.1.VI.1994. - In a pool in a garden. - Holomediterranean with a wide range from Central Europe to the Middle East and Middle Asia.

Hesperocorixa occulta (Lundblad, 1929). - Shams Abad 45 km SE of Kashmar, 4 exx, 23.VI.1994. - In pools on a hilly terrain. - Irano-Turanian.

Sigara (Pseudovermicorixa) nigrolineata (Fieber, 1848). - $15 \mathrm{~km}$ E of Bojnurd, 1 ex, 15.VII.1994. - In a gravelly brook. - European, extending to the Middle East.

Sigara (Sigara) seistanensis (Distant, 1920). — Lotfabad, many exx, 15.VI.1994. - Collected at light trap. Known from Iran, Middle and Central Asia and the Oriental Region.

Sigara (Tropocorixa) hoggarica (Poisson, 1929). Shams Abad 45 km SE of Kashmar, many exx, 23.VI.1994. - In pools on a hilly terrain. - Eremian.

Sigara (Vermicorixa) lateralis (Leach, 1817). — Many exx from $15 \mathrm{~km}$ of E Bojnurd, 16.VII.1994; Lotfabad, 15.VI.1994; Mashhad, V-VII.1994; Nodeh 30-40 km ESE of Bojnurd, 11.VII.1994; Parvand $70 \mathrm{~km}$ W of Sabzevar, 31.V.-1.VI.1994; near Sabzevar, 31.V.-1.VI.1994; Sarakhs, 29-30.IV.1994; 15-25 km N of Tabas, 14-15.V.1994; near Zaman Soofi $65 \mathrm{~km}$ W of Bojnurd, 12-13.VII.1994. Common in pools and brooks. - Holomediterranean, extending from Central Europe to Africa and Central and South Asia.

\section{Notonectoidea \\ Notonectidae \\ Notonectinae}

Notonecta maculata Fabricius, 1794. — Lake Bazangan $50 \mathrm{~km}$ W of Sarakhs, 1 ex, 30.VI.1994; Shams Abad $45 \mathrm{~km}$ SE of Kashmar, 1 ex, 23.VI.1994, - Known from Central Europe, the Mediterranean subregion and the Middle East.

Notonecta viridis Delcourt, 1909. — Shams Abad $45 \mathrm{~km}$ SE of Kashmar, $1 \mathrm{ex}, 23$.VI.1994. - In pools together with the preceding species. - Holomediterranean, extending to Central Europe, the Middle East, Middle Asia, Pakistan, and India.

\section{Gerromorpha \\ Hebroidea \\ Hebridae}

Hebrus pilipes Kanyukova, 1997. - Khalcanlod $30 \mathrm{~km} \mathrm{E}$ of Quchan, several exx, 7.VI.1994. - On wet stones in banks of a mountain brook. - Known from Russia, Ukraine, Armenia, Azerbaijan, Georgia, Turkmenistan, Uzbekistan, Tadzhikistan, Kazakhstan, and Iran.

\section{Hydrometroidea Hydrometridae}

Hydrometra stagnorum (Linnaeus, 1758). - $15 \mathrm{~km} \mathrm{E} \mathrm{of}$ Bojnurd, 4 exx, 15.VII.1994. - Among vegetation in a brook. - European, extending to North Africa, the Middle East and Middle Asia.

\section{Gerroidea \\ Veliidae \\ Veliinae}

Velia affinis affinis Kolenati, 1857. —Zoshk near Shandiz, several exx, 24.V.1994. — In a mountain brook. - IranoTuranian.

\section{Gerridae \\ Gerrinae}

Gerris (Gerris) costae (Herrich-Schaeffer, 1850). - Many exx from Khalcanlod $30 \mathrm{~km}$ E of Quchan, 7.VII.1994; Lake Bazangan $50 \mathrm{~km}$ W of Sarakhs, 30.VI.1994; Sarakhs, 29 30.IV.1994, RL; Mashhad, 21.V.1992, Modarres. — Among vegetation in pools and brooks. - Holomediterranean, extending to Middle Asia.

Gerris (Gerris) thoracicus Schummel, 1832. - Many exx from $15 \mathrm{~km}$ E of Bojnurd, 15.VII.1994; Lake Bazangan 50 km W of Sarakhs, 30.VI.1994; Sarakhs, 29-30.IV.1994; Zoshk near Shandiz, 24.V.1994. - Among vegetation in brooks and pools. - European, extending to North Africa, the Middle East and Middle Asia.

\section{Leptopodomorpha \\ Saldoidea \\ Saldidae \\ Saldinae}

Chartoscirta elegantula longicornis (Jakovlev, 1882). Lotfabad, 3 exx, 15.VI.1994. — Collected at light trap. Pontomediterranean. 
Saldula pallipes (Fabricius, 1784) - Khargh $70 \mathrm{~km}$ SW of Quchan, 1 ex, 8-9.VI.1994; Lotfabad, 6 exx, 15.VI.1994. - On the gravelly shore of a brook. - Holarctic, also known from the Oriental and Neotropical Regions.

Saldula sp.n. near setulosa (Puton, 1880). — Lotfabad, 4 exx, 15.VI.1994. - Collected at light trap. - Generally recorded as S. setulosa from Middle Asia. According to Lindskog (1995: 133) an undescribed species. The genuine $S$. setulosa occurs only in West Europe and Morocco. New for Iran.

\section{Cimicomorpha \\ Cimicoidea \\ Nabidae \\ Nabinae}

Himacerus (Aptus) maracandicus (Reuter, 1890). - Darreh Gaz, 1 ex, 15.VI.1994; Zaman Soofi 65 km W of Bojnurd, 1 ex, 12-13.VII.1994; Zard $100 \mathrm{~km}$ WNW of Bojnurd, 1 ex, 15.VI.1994. - On herbaceous plants in hilly habitats. Irano-Turanian.

Nabis (Aspilaspis) viridulus Spinola, 1837. - Several exx from $15 \mathrm{~km}$ E of Bojnurd, 15.VII.1994; Esfideh, 20.IV.1994; Golestan Park 150 km W of Bojnurd, 14.VII.1994; Lake Bazangan $50 \mathrm{~km}$ W of Sarakhs, 30.VI.1994; Parvand $70 \mathrm{~km} \mathrm{~W}$ of Sabzevar, 4.VI.1994. On Tamarix, - Holomediterranean, extending to Middle Asia.

Nabis (Aspilaspis) indicus (Stål, 1873). - Several exx from Lotfabad, 15.VI.1994; Sabzevar, 31.V.-1.VI.1994. On Tamarix. - Eremian, extending from Africa to Middle Asia.

Nabis (Halonabis) sareptanus Dohrn, 1862. - Several exx from Deh Shor near Tabas, 15.V.1994; Lotfabad, 15.VI.1994; Sabzevar, 31.V.-1.VI.1994. - On halophytes such as Suaeda, Atriplex and Artemisia in semideserts and salt marshes. - Irano-Turanian, extending from the Balcan Peninsula to Central Asia.

Nabis (Nabis) palifer Seidenstücker, 1954. — Many exx from Anbaran $30 \mathrm{~km}$ W of Sarakhs, 11.VII.1994; $70 \mathrm{~km}$ W of Darreh Gaz, 14.VI.1994; Deh Shor near Tabas, 16.V.1994; Kashmar, 22-23.VI.1994; Khargh $70 \mathrm{~km} \mathrm{~W}$ of Quchan, 8.VI.1994; Lake Bazangan 50 km W of Sarakhs, 30.VI.1994; Lotfabad, 15.VI.1994; Mashhad, V-VII.1994; Parvand $70 \mathrm{~km}$ W of Sabzevar, 4.VII.1994; Sabzevar, 31.V.1.VI.1994; near Tabas, 14-18.V.1994; Zaman Soofi $65 \mathrm{~km}$ W of Bojnurd, 12-13.VII.1994. - In moist habitats with Juncaceae and Cyperaceae. - Irano-Turanian, extending from the Balcan Peninsula and the Middle East to China.

Nabis (Nabis) punctatus A. Costa, 1847. - Nodeh 30 $40 \mathrm{~km}$ ESE of Bojnurd, 2 exx, 11.VII.1994; Mashhad, 3 exx, V-VII.1994. - On herbaceous plants in fields and gardens. - European, extending to Middle Asia.

Nabis (Nabis) pseudoferus transcaspicus Remane, 1962. - Several exx from Golestan National Park $150 \mathrm{~km}$
W of Bojnurd, 14.VII.1994; Golmakan $35 \mathrm{~km} \mathrm{NW}$ of Mashhad, 10.V.1994. - In hilly meadows. - Known from Iran and Turkmenistan.

Nabis (Tropiconabis) capsiformis Germar, 1838. near Tabas, 2 exx, 14-18.V.1994. - On herbaceous plants in fields and semideserts. - Intertropical, extending to the Mediterranean subregion and Middle and Central Asia.

\section{Anthocoridae Anthocorinae}

Temnostethus (Ectemnus) reduvinus parilis (Horváth, 1891). - Mashhad, 1 ex, V-VII.1994. - On Populus sp. Known from Caucasia and Iran.

Anthocoris minki pistaciae Wagner, 1957. - Several exx from Anbaran $30 \mathrm{~km}$ W of Sarakhs, 11.VII.1994; Darreh Gaz, 15.VI.1994; Kashmar, 22-23.VI.1994. — On Pistacia. - Recorded from Iran and Azerbaijan.

Anthocoris pilosus (Jakovlev, 1877). - Several exx from Anbaran $30 \mathrm{~km}$ W of Sarakhs, 11.VII.1994; Khargh $70 \mathrm{~km}$ W of Quchan, 8-9.VI.1994; Nodeh 30-40 km ESE of Bojnurd, 11.VII.1994. - On Salix and herbaceous plants in edges of forests, mountain meadows and gardens. Euro-Siberian.

Orius (Orius) niger (Wolff, 1811). — Golmakan $35 \mathrm{~km}$ NW of Mashhad, 1 ex, 10.V.1994; Nodeh 30-40 km ESE of Bojnurd, 1 ex, 11.VII.1994. — On herbaceous plants in meadows, gardens and fields. - Holopalearctic.

Orius (Orius) laevigatus (Fieber, 1860). $-15 \mathrm{~km} \mathrm{E}$ of Bojnurd, 1 ex, 15.VII.1994. - On herbaceous plants in a garden. - Holomediterranean, extending to Central Europe and Middle Asia.

Orius (Heterorius) vicinus (Ribaut, 1923). - Several exx from Khalcanlod $30 \mathrm{~km}$ E of Quchan, 7.VI.1994; Lotfabad, 15.VI.1994; Mashhad, V-VII.1994; Zaman Soofi $65 \mathrm{~km}$ W of Bojnurd, 12-13.VII.1994; Zoshk near Shandiz $40 \mathrm{~km}$ W of Mashhad, 11.IV.1994. - On deciduous trees and herbaceous plants such as Chenopodium and Mentha. - Holomediterranean, extending to Central Europe, the Middle East and Central Asia. New for Iran.

Orius (Heterorius) horvathi (Reuter, 1884). — Khargh $70 \mathrm{~km} \mathrm{SW}$ of Quchan, 5 exx, 8-9.VI.1994; Nodeh 30$40 \mathrm{~km}$ ESE of Bojnurd, 2 exx, 11.VII.1994. - On Asteraceae and other herbaceous plants hilly meadows. Euro-Siberian.

Orius (Heterorius) laticollis discolor (Reuter, 1884). - Mashhad, several exx, V-VII.1994. — On Salix. Pontomediterranean, extending to Middle Asia. New for Iran.

Orius (Dimorphella) albidipennis (Reuter, 1884). Several exx from $70 \mathrm{~km}$ W of Darreh Gaz, 14.VI.1994; Efine near Esfideh, 20.IV.1994; Khargh $70 \mathrm{~km} \mathrm{SW}$ of Quchan, 8-9.VI.1994; Parvand $70 \mathrm{~km} \mathrm{~W}$ of Sabzevar, 31.V.-1.VI.1994; Sarakhs, 29-30.IV.1994; near Tabas, 1617.VI.1994. - In steppes and semideserts on herbaceous plants such as Asteraceae. - Eremian, extending from Africa to Middle Asia. 


\section{Lyctocorinae}

Amphiareus obscuriceps (Poppius, 1909). - Mashhad, several exx, V-VII.1994. - On deciduous trees. — Widely distributed in the Far East, extending westwards to Middle Asia, Iran, Caucasia, Russia, Byelorussia, Hungary, and Romania.

\section{Pentatomorpha \\ Coreoidea \\ Coreidae \\ Coreinae}

Gonocerus acuteangulus (Goeze, 1778). - Near Zaman Soofi $65 \mathrm{~km} \mathrm{~W}$ of Bojnurd, 3 exx, 12-13.VII.1994. - On deciduous trees in a mountain forest. - Holomediterranean.

Coreus marginatus ( Linnaeus, 1758). - Anbaran $30 \mathrm{~km}$ W of Sarakhs, 2 exx, 11.VII.1994; Zoshk near Shandiz $40 \mathrm{~km}$ W of Mashhad, 2 exx, 11.IV.1994. - On undergrowth in mountain forests. - Euro-Siberian.

Syromastes rhombeus (Linnaeus, 1767). - Golestan National Park $150 \mathrm{~km}$ W of Bojnurd, 2 exx, 14.VII.1994. - On undergrowth in a mountain forest. - Holomediterranean.

Haploprocta pustulifera (Stål, 1859). — Chan Chiroc $50 \mathrm{~km} \mathrm{~S}$ of Tabas, 3 exx, 17.V.1994; Parvand $70 \mathrm{~km} \mathrm{~W}$ of Sabzevar, 1 ex, 4.VII.1994. - On halophytes such as Pteropyrum aucheri . - Turanian, extending to Mongolia.

Centrocoris volxemi (Puton, 1878). - Golestan National Park 150 km W of Bojnurd, 1 ex, 14.VII.1994; Parvand $70 \mathrm{~km} \mathrm{~W}$ of Sabzevar, several exx, 4.VII.1994. - On Chenopodiaceae halophytes. - Irano-Turanian.

Centrocoris inflaticeps Kiritshenko, 1916. - Sarakhs, 2 exx, 29-30.IV.1994. — On Chenopodiaceae halophytes in a salt marsh. - Irano-Turanian.

Phyllomorpha lacerata Herrich-Schaeffer, 1835. Parvand $70 \mathrm{~km}$ W of Sabzevar, 1 ex, 31.V.-1.VI.1994. Pontomediterranean.

\section{Pseudophloeinae}

Coriomeris validicornis Jakovlev, 1904. — Khargh $70 \mathrm{~km}$ SW of Quchan, 1 ex, 8-9.VI.1994. - In a mountain meadow. - Known from Iran and Transcaucasia.

Coriomeris vitticollis Reuter, 1900. - Khargh 70 SW of Quchan, 1 ex, 8-9.VI.1994. — In a mountain meadow. - Pontomediterranean.

\section{Rhopalidae}

Corizus hyoscyami (Linnaeus, 1758). $-70 \mathrm{~km}$ W of Darreh Gaz, 1 ex, 14.VI.1994; Zoshk near Shandiz $40 \mathrm{~km}$ W of
Mashhad, 3 exx, 21.V.1994. - On herbaceous plants such as Fabaceae and Asteraceae. - Euro-Siberian.

Liorhyssus hyalinus (Fabricius, 1794). - Deh Shor $25 \mathrm{~km} \mathrm{~N}$ of Tabas, 1 ex, 17.IV.1994; near Tabas, 2 exx, 14 18.V.1994. - On herbaceous plants in fields and semideserts. - Cosmopolitan.

Brachycarenus tigrinus (Schilling, 1829). - Several exx from Darreh Gaz, 15.VI.1994; Khalcanlod $30 \mathrm{~km}$ E of Quchan, 7.VI.1994; Khargh 75 km SW of Quchan, 89.VII.1994; Shourlogh $35 \mathrm{~km}$ SW of Sarakhs, 30.IV.1994; Zard $100 \mathrm{~km}$ WNW of Bojnurd, 13.VII.1994; Zoshk near Shandiz $40 \mathrm{~km}$ W of Mashhad, 24.V.1994. - In hilly meadows. - Holarctic.

Brachycarenus languidus (Horváth, 1891). - Darreh Gaz, 15.VI.1994; Khalcanlod $30 \mathrm{~km} \mathrm{E}$ of Quchan, 2 exx, 7.VI.1994; Shourlogh $35 \mathrm{~km} \mathrm{SW}$ of Sarakhs, $1 \mathrm{ex}$, 30.IV.1994. - Together with the preceding species. Irano-Turanian.

Rhopalus (Rhopalus) subrufus (Gmelin, 1790). Zaman Soofi $65 \mathrm{~km}$ W of Bojnurd, $1 \mathrm{ex}, 12-13 . V I I .1994$. - Euro-Siberian.

Rhopalus (Rhopalus) parumpunctatus Schilling, 1829. - Khalcanlod $30 \mathrm{~km}$ E of Quchan, 1 ex, 7.VI.1994. Euro-Siberian.

Rhopalus (Rhopalus) lepidus Fieber, 1861. - Several exx from $70 \mathrm{~km}$ W of Darreh Gaz, 14.VI.1994; Khargh $75 \mathrm{~km}$ SW of Quchan, 8-9.VII.1994; Lake Bazangan $50 \mathrm{~km}$ W of Sarakhs, 30.VI.1994; Zoshk near Shandiz $40 \mathrm{~km} \mathrm{~W}$ of Mashhad, 24.VI.1994. - In meadows. - Pontomediterranean.

Rhopalus (Rhopalus) curtulus (Kiritshenko, 1914). Khargh $75 \mathrm{~km}$ SW of Quchan, 1 ex, 7.VI.1994. - In a mountain meadow. - Irano-Turanian.

Stictopleurus pictus (Fieber, 1861). - Several exx from Anbaran $30 \mathrm{~km}$ W of Sarakhs, 11.VII.1994; Nodeh 30$40 \mathrm{~km}$ ESE of Bojnurd, 11.VII.1994; Roubat Sharaf $65 \mathrm{~km}$ SW of Sarakhs, 30.IV.1994; Zaman Soofi $65 \mathrm{~km}$ W of Bojnurd, 12-13.VII. 1994; Zoshk near Shandiz $40 \mathrm{~km}$ W of Mashhad, 11.IV.1994. — In fields and meadows. - Holomediterranean.

Stictopleurus subtomentosus (Rey, 1888), - Khalcanlod $30 \mathrm{~km}$ E of Quchan, 3 exx, 7.VI.1994. - In a hilly meadow. - Holomediterranean.

Maccevethus caucasicus (Kolenati, 1845). - Golmakan $35 \mathrm{~km}$ NW of Mashhad, 1 ex, 10.V.1994; Khargh 75 km SW of Quchan, 1 ex, 8-9.VII.1994; Nodeh 30-40 km ESE of Bojnurd, 1 ex, 11.VII.1994. - In mountain meadows. - Pontomediterranean.

Maccevethus corsicus Signoret, 1862. - Darreh Gaz, 1 ex, 15.VI.1994; Golestan National Park $160 \mathrm{~km}$ W of Bojnurd, 1 ex, 14.VII.1994; 15-25 km N of Tabas, 1 ex, 14-15.V.1994. - In hilly meadows. - Holomediterranean. Agraphopus suturalis Reuter, 1900. — Lotfabad, 1 ex, 15.VI.1994; Parvand 70-80 km W of Sabzevar, $1 \mathrm{ex}, 31$.V.1.VI.1994. - On grasses such as Aristida and Panicum. Eremian, extending from Africa to Middle Asia.

Chorosoma schillingi (Schummel, 1829). - Darreh Gaz, 1 ex, 15.VI.1994; 70 km W Darreh Gaz, 1 ex, 
14.VI.1994; Golestan National Park $160 \mathrm{~km}$ W Bojnurd, $1 \mathrm{ex}, 14$.VII.1994. — On grasses in mountain meadows. European, extending to Middle Asia.

Chorosoma gracile Josifov, 1968. - Parvand $80 \mathrm{~km}$ W of Sabzevar, several exx, 31.V.-1.VI.1994. - In dunes on Stipagrostis sp. - Pontomediterranean.

\section{Pyrrhocoridae}

Pyrrhocoris apterus (Linnaeus, 1758). - Zaman Soofi $65 \mathrm{~km}$ W of Bojnurd, $1 \mathrm{ex}, 12-13$. VII.1994. - Holarctic.

Acknowledgements. The authors are greatly indebted to the Dean, Dr. M. H. Rashed and other members of the Faculty of Agriculture of the Ferdowsi University for all cooperation received during the expedition. We thank the
Finnish Society of Sciences and Letters, Helsinki, for financial help.

\section{References}

Aukema, B. \& Rieger, Chr. (eds.) 1995: Catalogue of the Heteroptera of the Palaearctic Region. Vol. 1. - The Netherlands Entomological Society. 222 pp.

Aukema, B. \& Rieger, Chr. (eds.) 1996: Catalogue of the Heteroptera of the Palaearetic Region. Vol. 2, - The Netherlands Entomological Society. 361 pp.

Lindskog, P. 1995: Infraorder Leptopodomorpha. - In: Aukema, B. \& Rieger, Chr. (eds.), Catalogue of the Heteroptera of the Palaearctic Region. Vol. 1: 115-141.

Moulet, P. 1995: Hémiptères Coreoidea Euro-Méditerranéens. - Faune de France 81, Paris. 336 pp. 


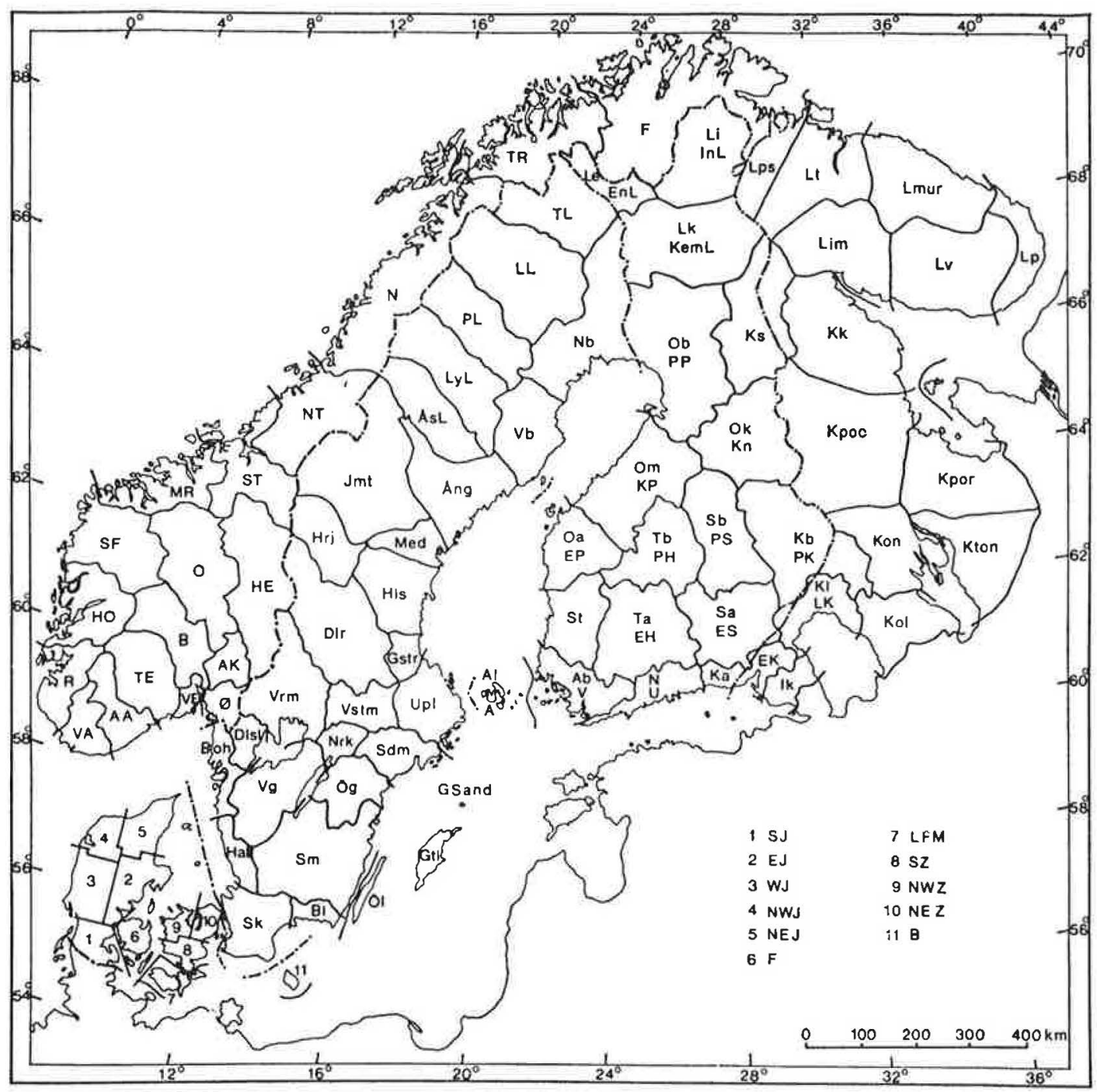

The biogeographical provinces of Fennoscandia and Denmark 